УДК 620.2:658.6

Н. В. ЛИСЕНКО

Полтавський науково-дослідний експертно-криміналістичний центр Міністерства внутрішніх справ України

\title{
ТОВАРОЗНАВЧА ЕКСПЕРТИЗА ПОЛІМЕРНИХ ПАКЕТІВ ТИПУ МАЙКА ТОВ «КОМСЕРВ УКРАЇНА»
}

\author{
Н. В. ЛЫСЕНКО
}

Полтавский научно-исследовательский экспертно-криминалистический центр

Министерства внутренних дел Украинь

\section{ТОВАРОВЕДЧЕСКАЯ ЭКСПЕРТИЗА ПОЛИМЕРНЫХ ПАКЕТОВ ТИПА МАЙКА ООО «КОМСЕРВ УКРАИНА»}

\author{
N. LYSENKO \\ Poltava Scientific-Research Experimental Forensic Centre Ministry of Interior of Ukraine \\ COMMODITY EXPERTISE OF POLYMERIC PACKAGES OF \\ LTD «COMSERV UKRAINE»
}

\section{https://doi.org/10.36910/6775-2310-5283-2019-12-16}

Мета. 3'ясування особливостей проведення експертизи пакетів полімерних типу майка виготовлених ТОВ «Комсерв Україна» для встановлення відповідності показників їх споживних властивостей вимогам чинних нормативних документів.

Методика. Під час проведення товарознавчої експертизи були використані наступні методи дослідження: органолептичні (дослідження маркування, визначення типу, перевірка зовнішнього вигляду та швів полімерних пакетів, ідентифікації полімерного матеріалу), вимірювальні (розривальне навантаження, розмірні характеристики).

Результати. Визначено доиільність проведення товарознавчої експертизи полімерних пакетів, так як у сучасній промисловості неможливе виробничтво товарів без належного упакування. Упаковка - це засіб чи комплекс засобів, щзо забезпечує захист продукиії від пошкодження і втрат, навколишнього середовища - від забруднень, а також прочес обігу продукиії. У статті представлено розроблений порядок проведення товарознавчої експертизи полімерних пакетів типу майка, який включає такі основні етапи: аналіз документів, ідентифікація об'єкта дослідження, дослідження показників споживних властивостей, аналіз одержаних результатів, формулювання обтрунтованої аргументованої відповіді на запитання, поставлене на вирішення перед експертом. Представлено результати товарознавчої експертизи, якими встановлено, щзо надані для дослідження полімерні пакети (тип майка, виробництво ТОВ «Комсерв Україна») за наявним маркуванням відповідають вимогам ДСТУ 4260:2003 Тара $i$ паковання спожиткові. Марковання. Загальні вимоги. Це дало змогу ідентифікувати пакети $з$ урахуванням природи пакувального матеріалу та його виробника. Визначити иляхи подальшого їх використання. Внутрішня поверхня пакетів не злипається; пакети художньо оформлені; шви шириною 0,1 мм розташовувані від краю пакета на відстані 10 мм; шви пакетів рівні, без пропалених місиь та зморшок, герметичні. За досліджуваними 
показниками - розмірні характеристики, ширина шва, його розміщення та якість, матеріал виготовлення, товщини плівки, відповідають вимогам регламентованими ДСТУ 7275:2012 Пакети з полімерних та комбінованих матеріалів. Загальні технічні умови та не відповідають встановленим вимогам за значенням показника мічність при розриві.

Практична значимість. Розроблений та апробований порядок проведення товарознавчої експертизи полімерних пакетів може бути використано під час проведення експертиз експертними організаціями, у ході який встановлюється відповідність показників споживних властивостей вимогам чинних нормативних документів або умовам контракту.

Ключові слова: полімерні пакети, споживні властивості, товарознавча експертиза.

\section{Постановка проблеми у загальному вигляді та її зв'язок із} важливими науковими чи практичними завданнями. Полімерна упаковка - засіб або комплекс засобів, які забезпечують захист товару від пошкоджень та втрат, а також полегшують його транспортування, зберігання і реалізацію. Найважливішим елементом упаковки є тара. Полімерна тара являє собою виріб для розміщення продукції, виконаний у вигляді відкритого або замкнутого порожнистого корпуса [1]. Пакети із поліетилену та комбінованих матеріалів на сьогоднішній день $є$ найпоширенішим, універсальним i доступним за ціною та способом зберігання і транспортування видом тари для переважної більшості товарів. Серед переваг використання даного виду тари можна відмітити широку сферу застосування і відмінні експлуатаційні характеристики. Крім того, полімерні пакети є носіями рекламної інформації. Проте, гарний і зручний пакет, не придатний для багаторазового використання i через короткий час вже є частиною сміття. Причому, пакети із полімерних матеріалів не піддаються утилізації і потребують багатьох сотень років для повного розкладання, що ставить перед суспільством актуальну проблему раціонального їх використання та утилізації [2]. Беззаперечно важливим $\epsilon$ екологічних аспект застосування полімерних пакетів, проте актуальним лишається й питання якості полімерних пакетів, оскільки вони мають високий рівнем використання в побуті та торгівлі.

Аналіз останніх досліджень, у яких започатковано вирішення проблеми. Проблемі якості полімерної тари присвячені роботи таких науковців як Сирохмана I. В., Завгородньої В. М., Дядічева В. В., Сфремова Н. Ф. Вирішенню питанню утилізації полімерної тари присвячені роботи Шаповал Г. С., Мантуло О. П., Третьякова А. О., Бабаева В. Н.

Ціль статті полягає у розробці та апробації алгоритму товарознавчої експертизи полімерних пакетів типу майка виробництва ТОВ «Комсерв Україна» 3 метою визначення відповідності показників їх споживних властивостей вимогам нормативних документів. 
Об’єктом дослідження $є$ пакети полімерні типу майка серії «без малюнка» виробництва ТОВ «Комсерв Україна».

Методи дослідження. Під час проведення товарознавчої експертизи полімерних пакетів були використані наступні методи дослідження: органолептичні (дослідження маркування, визначення типу, перевірка швів полімерних пакетів), вимірювальні (розмірні характеристики, розривальне навантаження).

Виклад основного матеріалу дослідження 3 повним обгрунтуванням отриманих наукових результатів. Для вирішення поставленого завдання, а саме одержання об'єктивного, компетентного, незалежного висновку експерта було розроблено програму експертизи. Програма експертизи - це комплекс положень, що визначають цілі та завдання дослідження, предмет і умови його проведення, використовувані ресурси, а також передбачуваний результат. Вона $\epsilon$ засобом досягнення мети, формою іiі конкретизації. Програма розроблялася виходячи із запитань, які були поставлені замовником перед експертом. Програма експертизи включала такі основні етапи:

- аналіз документів;

- ідентифікація (ідентифікація об'єкта та упакування описовим методом; встановлення наявності маркування та його характеристика);

- дослідження показників споживних властивостей, аналіз одержаних результатів (аналіз марковання, встановлення типу, вимірювання розмірних характеристик, вимірювання ширини шва, його розміщення та якість, дослідження матеріалу виготовлення, товщини плівки, розривних характеристик).

- формулювання обгрунтованої аргументованої відповіді на запитання, поставлене на вирішення перед експертом.

На дослідження представлений об'єкт - разова споживча м'яка тара із полімерного матеріалу 3 корпусом у формі рукава, 3 дном і відкритою горловиною, місткістю до 20,0 дм³, отже це пакети [3]. Пакети упаковані в спеціальний запаяний прозорий безкольоровий пакет із полімерного матеріалу, що забезпечує захист продукції від пошкоджень та втрат, забруднення, а також дозволяє транспортування, зберігання та реалізацію продукції, призначена для одиниці продукції, тобто індивідуальну упаковку.

На лицьовій стороні упаковки фарбою синього кольору нанесено наступну інформацію: логотип виробника - «COMSERV»; дата - 06.2016 р.; повна назва фірми - ТОВ «Комсерв Україна»; адреса - м. Харків; сайт виробника - www.comserv.com.ua; електронна е-мейл адреса - 
comserv.ua@gmail.com; термін придатності - необмежений; кількість в упаковці - 100 шт.; придатність - придатні для харчових та промислових товарів; інформація про безпечність продукції - Безпечне пакування, схвалено «Асоціацією ПРРГУ»; відповідає вимогам Системі управління Якістю ДСТУ, ISO 9001:2009; зверху присутній артикул товару - 0250002108432; стандарт згідно якого було виготовлено полімерні пакети - ТУ У 25.22632916536-001-2004; наявні інформаційні знаки: а) 马飞"] Екологічний знак «Келих-вилка». На сучасній упаковці найчастіше наноситься знак - заклик не забруднювати природу. При цьому в різних країнах близько цього знаку можуть бути різні написи - від «Бережіть працю прибиральниць» до «Викидати у відро для сміття», але зміст цих написів однаковий; б) Ре-но Екологічний знак «переробляється» інформує про те, що упаковка або товар придатні для вторинної переробки. При цьому в сам знак вставлено цифри 02 - код речовини, з якої виготовлено товар або його упаковка.

На лицьовій стороні упаковки фарбою червоного кольору нанесено: розмір пакета - 22+(2 х 5)х40; праворуч у куті напис «СУПЕР».

Отже, у ході ідентифікації встановлено, що об'єктом дослідження $\epsilon$ полімерні пакети виробництва ТОВ «Комсерв Україна».

Дослідження зразка проводилися у лабораторії за температури $20{ }^{\circ} \mathrm{C}$, при денному освітленні та відносній вологості повітря $60 \%$ згідно вимог. На першому етапі дослідження було проаналізовано марковання 3 метою встановлення його відповідності вимогам ДСТУ 7275:2012 [4].

Проаналізувавши марковання на відповідність вимогам ДСТУ 7275:2012 [4] та $з$ урахуванням вимог ДСТУ 4260:2003 Тара і паковання спожиткові. Марковання. Загальні вимоги [5] встановлено, що реквізити маркування досліджуваних полімерних пакетів відповідають вимогам, оскільки на пакування нанесена наступна інформація: найменування країни-виробника; найменування підприємства-виробника, його юридична адреса та контактні телефони; товарний знак; найменування, призначення, тип і розміри пакета; дата виготовлення (місяць, рік); термін зберігання; позначення технічної документації; напис «Для харчової продукції»; символ екологічного маркування (петля Мебіуса) із зазначенням умовного позначення матеріалу (абревіатури або цифрового коду), з якого виготовлені пакети.

На наступному етапі дослідження було визначено тип полімерного пакету за ДСТУ 7275:2012 [4]. У результаті визначення типу встановлено, що досліджуваний полімерний пакет відноситься до типу - пакет «з прямим 
дном», згідно з ДСТУ 7275:2012, креслення на якому повністю відповідає зразку пред'явленого на експертизу. Відповідно до розробленої програми експертизи, далі досліджено зовнішній вигляд, якість швів та встановлено вид полімерного матеріалу, з якого виготовлено пакет.

Якість поверхні пакетів, крім швів, має відповідати вимогам технічної документації на полімерні плівки і комбіновані матеріали, з яких виготовлені пакети. Перевіркою показників зовнішнього вигляду полімерних пакетів типу майка, виробництва ТОВ «Комсерв Україна» згідно з ДСТУ 7275:2012 [4] встановлено, що: поверхня без тріщин, розривів та отворів; пакети мають шви шириною 0,1 мм; шви розташовані на відстані 10 мм; шви пакетів герметичні, та рівні по всій довжині, без складок; пакети не мають злипань внутрішніх поверхонь; клейовий шов рівний, без не проклеєних місць і складок; зсув художніх елементів відсутній. За результатами дослідження зовнішнього вигляду пакетів полімерних, можна зробити висновок про їх відповідність вимогам ДСТУ 7275:2012 [4].

Далі було визначено вид полімерного матеріалу з якого виготовлений об'єкт експертизи - пакети полімерні типу майка, серії «без малюнка», виробництва ТОВ «Комсерв Україна». Для цього використано загальноприйняту систему ідентифікації полімерів [6].

Для визначення виду полімеру невеликий кусок полімерного пакета поміщали в воду, він не тонув, це свідчить, що для виготовлення досліджуваного полімерного пакету використано поліетилен або поліпропілен. Для більш точного визначення підпалювали зразок, під час горіння спостерігали голубуватий колір полум'я. У повітрі відчувався добре виражений запах парафіну. Згорання проходило швидко. При згоранні зразок плавився, залишаючи при цьому каплі.

Провівши дослідження зразка полімерного матеріалу з якого виготовлено пакети полімерні, які представлені на експертизу можна стверджувати що це поліетилен, оскільки при дослідженні він проявив особливості характерні для поліетилену по системі ідентифікації полімерів.

Далі було проведено вимірювання товщини плівки, яка використовувалася для виробництва пакетів полімерних ТОВ «Комсерв Україна» типу майка за допомогою мікрометра. Вимірювання товщини плівки пакетів полімерних проводили 3 рази. Перший вимір проводили на відстані 10 мм від бокового шва пакету, наступні - через кожні 50 мм. У результаті вимірювань отримали середню товщину пакетів полімерних типу майка виробництва ТОВ «Комсерв Україна» - 0,01 мм. 
Вимірювання показника міцність при розриві проводили за стандартною методикою, згідно з ГОСТ 14236-81 [7]. Для проведення дослідження використовували зразки з розмірними характеристики 25х150 мм. Результати проведення досліджень розривних характеристик представлені в таблиці 1.

Таблиця 1

Результати вимірювання розривних характеристик пакетів поліетиленових типу майка, серії «без малюнка» ТОВ «Комсерв Україна»

\begin{tabular}{|c|c|c|c|}
\hline $\begin{array}{c}\text { № } \\
\text { зразка }\end{array}$ & $\begin{array}{c}\text { Значення розривного } \\
\text { навантаження, кгс }\end{array}$ & $\begin{array}{c}\text { Значення площі поперечного } \\
\text { перерізу, см² }\end{array}$ & $\begin{array}{c}\text { Міцність при } \\
\text { розриві, кгс/см² }\end{array}$ \\
\hline 1 & 33 & 0,25 & 132,0 \\
\hline 2 & 33 & 0,24 & 137,5 \\
\hline 3 & 34 & 0,25 & 136,0 \\
\hline
\end{tabular}

Отже, пакети поліетиленові ТОВ «Комсерв Україна» не відповідають вимогам за розривними показниками оскільки мають міцність при розриві менше 165 кгс/см², що не допускається ГОСТ 10354-82 Плёнка полиэтиленовая. Технические условия [8].

За результатами проведених досліджень показників споживних властивостей полімерних пакетів типу майка ТОВ «Комсерв Україна» можна зробити висновок, що вони за такими показниками як маркування, тип, якість швів, розмірні характеристики відповідають встановленим вимогам ДСТУ 7275:2012 Пакети з полімерних та комбінованих матеріалів. Загальні технічні умови та не відповідають за значенням показника міцності при розриві.

Висновки та перспективи подалыших досліджень. У ході проведення товарознавчої експертизи полімерних пакетів типу майка ТОВ «Комсерв Україна» було встановлено відповідність показників їх споживних властивостей вимогам чинних нормативних документів. Перспективи подальших досліджень у даному напрямі будуть спрямовані на вдосконалення алгоритму проведення експертизи полімерної тари 3 метою його впровадження у використання експертними установами.

\section{Список використаних джерел}

1. Сирохман I. В. Товарознавство пакувальних товарів і тари: підручник [для студ. вищ. навч. закл.] / І. В. Сирохман, В. М. Завгородня. - К.: Центр учбової літератури, 2009. $616 \mathrm{c}$.

2. Технології захисту навколишнього середовища [Електронний ресурс]: Промислова екологія. Технології захисту навколишнього середовища. Режим доступу: eco.com.ua/sites/eco.com.ua. 
3. Картка даних терміну пакет // Національний банк стандартизованих науковотехнічних термінів [Електронний ресурс]: Офіційний сайт Державного підприємства «Український науково-дослідний і навчальний центр проблем стандартизації, сертифікації та якості». Режим доступу: http://uas.org.ua/ua/bank-danih/natsionalniy-bankterminiv/znachennya-termina/?term-id $=56979$.

4. ДСТУ 7275:2012 Пакети 3 полімерних та комбінованих матеріалів. Загальні технічні умови. - Чинний від 01.03.2013. - Київ: Мінекономрозвитку, 2013 - 14 с.

5. ДСТУ 4260:2003 Тара і паковання спожиткові. Марковання. Загальні вимоги. Чинний від 01.10.2004. - Київ: Держспоживстандарт України, 2005 - 16 с.

6. Система идентификации полимеров // Методы идентификации полимеров [Електронний ресурс]: Официальный сайт ПЛАСТИНФО. Режим доступу: https://plastinfo.ru/information/articles/220/.

7. ГОСТ 14236-81 Пленки полимерные. Метод испытания на растяжение - Чинний від 01.07.1981. - М.: Государственный комитет ССР по стандартам, 1981 - 10 с.

8. ГОСТ 10354-82 Пленка полиэтиленовая. Технические условия. - Чинний від 01.07.1983. - М.: Стандартинформ, 2007 - 23 с.

Цель. Определение особенностей проведения экспертизы пакетов полимерных типа майка изготовленных ООО «Комсерв Украина» для установления соответствия показателей их потребительских свойств требованиям действующих нормативных документов.

Методика. Во время проведения товароведческой экспертизы были использованы следуюшие методы исследования: органолептические (исследования маркировки, определение типа, проверка внешнего вида и швов полимерных пакетов, идентификации полимерного материала), измерительные (разрывной нагрузки, размерные характеристики).

Результаты. Определена целесообразность проведения товароведческой экспертизы полимерных пакетов, так как в современной промышленности невозможно производство товаров без надлежащей упаковки. Упаковка - это средство или комплекс средств, обеспечивающий защиту продукиии от повреждения и потерь, окружающей среды - от загрязнений, а также проиесс обращуения продукции. В статье представлен разработанный порядок проведения товароведческой экспертизы полимерных пакетов типа майка, который включает следуюшие основные этапы: анализ документов, идентификация объекта исследования, исследования показателей потребительских свойств, анализ государственных результатов, формулирование обоснованной аргументированного ответа на вопрос, заданный на решение перед экспертом. Представлены результаты товароведческой экспертизы, которыми установлено, что предоставленные на исследование полимерные пакеты (тип майка, производство ООО «КОМСЕРВ Украины») по имеюшийся маркировке соответствуют требованиям ДСТУ 4260: 2003 Тара и упаковка употреблению. Маркировка. Общие требования. Это позволило идентифицировать пакеть с учётом природы упаковочного материала та его производителя. Определить пути дальнейшего их использования в случае решения проблемь внедрения системы сбора и переработки. Внутренние поверхности пакетов не слипаются; пакеты художественно оформлены; швы шириной 0,1 мм размещены от края пакета на 10 мм; швы пакетов ровные, без прожженных мест и морщии, герметичны. По исследуемым показателям - размерные характеристики, иирина шва, его размещения и качество, материал изготовления, толщина плёнки, соответствуют требованиям регламентированными ДСТУ 7275:2012 Пакеть из полимерных и комбинированных 
материалов. Общие технические условия и не отвечают установленным требованиям по значению показателя прочность при разрыве.

Практическая значимость. Разработан и апробирован порядок проведения товароведческой экспертизы полимерных пакетов может быть использовано при проведении экспертиз экспертными организачиями, в прочессе которых устанавливается соответствие показателей потребительских свойств требованиям действуюших нормативных документов или условиям контракта.

Ключевые слова: полимерные пакеты, показатели потребительских свойств, товароведческая экспертиза.

Purpose. Clarification of the peculiarities of conducting expertise of polymeric packages made by Ltd "Comserv Ukraine» for establishing correspondence of the indicators of their consumer properties with the requirements of the current normative documents.

Methodology. During the course of commodity expertise the following research methods were used: organoleptic (marking research, type determination, check of appearance and checking of seams of polymeric package, identification of polymer material), measuring (breaking load, dimensional characteristics).

Findings. The expediency of conducting the commodity expertise of polymeric packages was defined as the modern industry the production of goods is impossible without proper packing. Packing is the mean or the complex of means providing protection of products against damages and losses, the environment - against pollution and also the process of the addressing of products. The article describes the procedure of conducting commodity expertise of polymeric packages which includes the following main stages: analysis of documents, identification of the object of research, research of indicators of consumer properties, analysis of the state results, and formulation of a substantiated reasoned solution of the problem the expert faced with. The results of commodity expertise are presented. It is established that the polymeric packages provided for the research produced by Ltd «Comserv Ukraine» with its marking corresponds the requirements of DSTU 4260:2003 Consumer package and packing. Marking. Basic principles. It allowed to identify packages accounting the nature of the packing material and its producer the ways of their further usage in case of a solution of the problem of providing of a system of collecting and processing. Internal surfaces of packages do not stick together; the packages are aptly issued; seams $0.1 \mathrm{~mm}$ wide are placed on $10 \mathrm{~mm}$ from the edge of the package; seams of packages are equal, without the burned places and wrinkles, tight. On the studied indicators - dimensional characteristics, width of a seam, its placement and quality, production material, film thickness conform to requirements regulated by DSTU 7275:2012 Bags made of polymeric and composite materials. General specifications and also do not meet the established requirements for value of an indicator durability at a gap.

The practical value. The developed and tasted procedure of carrying out commodity expertise of polymeric packages can be used during conducting such kinds of examinations by the expert organizations, in the course of which the compliance of indicators of consumer properties to requirements of the existing normative documents or to terms of the contract is being established.

Keywords: polymeric packages, indicators of consumer properties, commodity expertise.

Стаття рекомендована до публікачіі доктором технічних наук, професором ПУЕТ Кожушком Г.М. Дата надходження в редакиію 19.02.2019 p. 